\title{
The Effect of Digital Documentary Production through Field Work on Geography Students' Problem-Solving Skills*
}

\author{
Rukiye Adanalı \\ Correspondence: Rukiye Adanal, Department of Geography Teaching, Ataturk University, Erzurum, Yakutiye, Erzurum, \\ Turkey.
}

Received: December 7, 2017

doi:10.11114/jets.v6i1.2847

\author{
Accepted: December 21, 2017 \\ Online Published: December 23, 2017 \\ URL: https://doi.org/10.11114/jets.v6i1.2847
}

\begin{abstract}
In this study, views of students about the applicability of the digital documentary production through fieldwork model and the effect of it on their problem-solving skills were examined. The study was conducted in Turkey, in 2016-2017 spring term with 15 geography teacher candidates who chosen by convenience sampling method. In this study, within producing student digital documentary via fieldwork (FwDD) which is the outcome of the project-based learning (PBL) process, students were asked to carry out field works and to reflect their observations through a digital documentary, on Cultural Geography subjects. The data was collected through Problem-Solving Inventory and focus group interviews, in this case study. Paired Samples Test and content analysis were used for analysis of the data. The findings showed that FwDD-PBL lead to a significant difference regarding the students' problem-solving skills since the effect size is 0.61 . Students stated that they learned to use the technology for educational and reflective purposes, that the project increased their motivations and enterprisingness besides their creative thinking and decision-making skills. The study is important to provide the students effective instruction and teaching skills. It is expected that the results will be useful to encourage the use of FwDD-PBL model in geography education.
\end{abstract}

Keywords: problem-solving skill, project-based learning, digital documentary production, fieldwork, cultural geography

\section{Introducation}

Digital technology is growing with every passing day and penetrating into every area from social life to education, consumption habits to people's working styles. Especially, screen technology in which texts, sounds, and images are used together on today's digital native students' learning culture is gradually superseding the printed books that are keystone of education (Tüzel, 2013). According to social media statistics for 2017 (www.socialbusinesstr.com): Facebook users watch 8 billion videos a day; they watch videos at the rate of 51\% over mobile devices. Therefore, it has become a state of necessity that educators should integrate social media, smart phones and video elements, being students' basic three areas of interest, into the learning environments. As a matter of fact, being good at information-media and technology literacy is also one of the $21^{\text {st }}$ century 's skills (Kotluk \& Kocakaya, 2015).

Movies and documentaries are indispensable sources for this field since it is not always possible to obtain on-site inspection and information in geography (Demiralp, 2007; Di Palma, 2009) and the shooting of educational short films and sharing via the internet offer in-class and out-of-class learning opportunities (Akbaş, 2011; Akbaş, Canoğlu, \& Ceylan, 2015).In this study, the students tried to introduce the cultural and historical units of the city of Erzurum through the documentaries they produced in field works. Geography students in higher education collect and interpret geographical data in scientific trips and field works (Garipağaoğlu, 2001; Doğanay, 2002). In fieldworks, students have the opportunity to observe their environment from a geographical point of view and apply theoretical geography knowledge. In this sense, students are expected to acquire skills and attitudes such as learning by doing, critical thinking, researching, interpreting, synthesizing and solving problems, creating awareness of the environment (Gök \& Girgin, 2001; Balc1, 2010; Tuna, 2012; Şahin \& Özey, 2013).Geography teachers often have to carry out field experiences enriched with various activities in order to be able to interpret geographical phenomena and events effectively in their

\footnotetext{
*This research was presented orally at International Congress on the 75th Anniversary of Turkish Geographical Society between 08-10 November 2017 in Ankara, Turkey
} 
professional lives, otherwise, they can not teach to their students how to observe and research (Garipağaoğlu, 2001; Artvinli, K1liçarslan, \& Bulut, 2003).It is necessary for the teacher candidates to carry out activities to develop effective instruction and teaching skills at their undergraduate courses (Artvinli et al., 2003; Köşker, 2012; Doğan, 2016).

Although educational films and documentaries have been all along used on the learning environments, students themselves have been already engaged into their own digital medias, instead of being passive recipients in social media ( Ferster, Hammond, \& Bull, 2006; Siegle, 2009). Today, with the combination of information and technology, it has become quite easy to shoot short films and share them in a social media environment, with cameras adapted to mobile phones and computers (Akbaş, 2011; Yiğit et al., 2017). Digital documentaries (student educational short videos/student videos) are short films prepared by students with their own vocalization, including images, text or video montage (Kajder, 2004; Ferster et al., 2006). Documentary videos cover the topics designed on reality and may contain interviews (Akbaş, 2011; Morgan, 2013). In this sense, this research is separated from the digital storytelling.

Akbaş (2011), Akbaş et al. (2015) and Yiğit et al. (2017), evaluated the short films of the teacher candidates within the framework of technological-pedagogical content knowledge, in Turkey. Urhan (2016) used student-digital documentary as a reflection tool in her collaborative project-based work. Akbaş et al. (2015) and Urbano \& Urbano (2008), point out that video for education contributes to lifelong learning and the self-learning process. Educational films and videos encourage sharing of information in social media environments and develop the learning and teaching skills of the students who ask themselves that question: "How can I teach others?" (Kajder, 2004; Urbano \& Urbano, 2008; Akbaş, 2011; Yiğit et al., 2017; Bene, 2013; Morgan, 2013;Akbaş et al., 2015 ).

There are a variety of studies on cognitive and social skills gained by producing their own digital documentary from secondary to higher education. The results of these studies can be summarized as follows: Student videos are described as a meta-cognitive activity as well as an opportunity to develop multimodal literacy (Ranker, 2007; Urbano \& Urbano, 2008; Siegle, 2009; Bene, 2013; Morgan,2013); video creation allows students to make creative decisions in collaboration, planning and organizing, structure of images, order and rhythm (Akbaş, 2011; Bene, 2013; Morgan,2013); the video, a social cognitive tool, creates an environment that allows learning with peers and technology and it motivated students (Siegle, 2009; Swan, Hofer \& Swan, 2011; Akbaş,2011; Bene, 2013). The digital video production activity, when properly designed on a curriculum framework, students have the potential to gain metacognition, reflection, problem-solving, critical and creative thinking, self-regulated learning and academic skills (Kajder, 2004; Ferster et al., 2006; Urbano \& Urbano, 2008; Siegle, 2009; Akbaş, 2011; Bene, 2013; Morgan,2013; Yiğit et al., 2017).

The students who produced educational films in Urbano \& Urbano (2008)'s study stated that producing film was helped them to own and take responsibility for their own issues; that helped them to understand the content of the course through their own perspective. Real-life applications are included in the lessons, and the students' own knowledge is structured and made meaningful by them at Ausubel's meaningful learning and constructivist teaching theories (Russell, 2006, Bıyıkl1, Veznedaroğlu, Öztepe \& Onur, 2008). In this sense, the theoretical basis of student videos are based on the meaningful learning and constructivist learning approaches.

The practical nature of project-based learning is well suited to the nature of video production (Urbano \& Urbano, 2008; Akbas, 2011; Akbas et al., 2015; Yiğit et al., 2017). In the rich learning environment provided by project-based learning centered on real-life problems, students gain some lifelong learning skills, from collaborative and systematic working skills to high-level thinking skills, resulting in a product that the student believes in the success (Dede \& Yaman, 2003; Coşkun, 2004; Kalayc1, 2008; Coşkun, 2010; Kaplan \& Coşkun, 2012). John Dewey's "Reconstruction", Kilpatrick's "Project Method", Bruner's "Discovery Learning Approach" and Thelen's "Group Study Models" are the philosophical foundations of PBL (Korkmaz \& Kaptan, 2001). PBL also allows students to conduct research outside the classroom and to evaluate each other's project products (Dede \& Yaman, 2003, Coşkun, 2004, Kalayc1, 2008, Coşkun, 2010; Kaplan \& Coşkun, 2012). Coşkun (2010) and Urhan (2016) measured reflective thinking skills in project-based learning. Coşkun (2004) suggested that project-based learning would increase effective and persistent learning; he presented various plans and suggestions for project-based learning process in geography education. In the studies of Akbaş (2011) and Yigit et al., (2017), they evaluated educational short films produced by teacher candidates in the project-based learning process in education technologies and material development courses.

Student-produced digital documentaries might have an important potential for geography teacher candidates in gaining effective instruction and teaching skills before their professional lives. When videos that are an outcome of project-based learning method are supported by field works, students are supposed to make meaningful learning and to establish the connection of geography with life. In Turkey, in geography education, there is a need for studies of problem-solving and project-based learning approaches studies in which student-digital documentary production strategy is adapted to them.

Considering the literature, the common achievements of project based learning, fieldwork and student digital 
documentary are briefly as follows: Gaining collaborative and multidisciplinary working skills, development of creative, critical and problem-solving skills, outdoor education activities, learning the scientific research processes, using technology efficiently, developing reflective and metacognitive thinking, and the theoretical backgrounds of each are based on constructivist and meaningful learning. These common features make it possible to combine fieldwork and student-digital documentary project within the context of project-based learning. In this research, it is expected that the prospective teachers will learn project-based learning approach and obtain other specified skills as well.

The researcher observed at the Cultural Geography fieldworks in previous years, at her lessons, that the interest of students towards the local architectural and other culture units was weak and they were passive in the process. In order to increase the effectiveness of the fieldworks and course, the researcher asked them to carry out fieldwork themselves and to produce digital documentaries with their smartphones. In addition to this, students were requested to use their smart devices and social media as a means to increase their geographical knowledge and skills. As a matter of fact, prospective teachers use smart devices and social media especially to fill their leisure time (Alım \& Siyamoğlu, 2017).

According to Di Palma, students should be asked to create their own films in the applications which they are active and the images are converted into scientific knowledge. So that they can find solutions, to the technical and content problems of films by using their own geographical knowledge. Students should create their own films to improve their critical thinking skills as well as general cinema knowledge (Girgin, 2012; Swimelar, 2012; Metzger, 2010; Di Palma, 2009; Birkök, 2008). In this sense, it is expected that the students will develop their media literacy and critical thinking skills.

This study is important in that it is an example of how the student-made digital documentary activity can be used in geography education. It is also a new proposal for more effective implementation of fieldwork and projects by increasing students' motivation. Finally, it is important that prospective teachers are able to gain effective teaching and instructional skills, taking into account the question "how can I teach better?" It is expected that this research will contribute to these issues in geography education.

The research sought for answers to the following questions:

1) What are teacher candidates' opinions on the usability of FwDD-PBL learning model?

2) What is the effect of the FwDD-PBL model on the problem-solving skills of prospective teachers?

\section{Method}

\subsection{Research Design}

Case study method of qualitative research-based was used in the study. In this pattern, various methods are used while collecting data and a case is described in-depth. According to Creswell (2007), the case study is a qualitative research that a bounded case or more than one case are examined in detail and that data are collected. Interaction among environment, individuals, cases and process, which constitute a certain case, is examined by a holistic approach (Yin, 2003; Yıldırım \& Şimşek, 2012). This research model was used in order to describe in more detail students' experiences and attainments about the process of digital documentary production project through field work.

\subsection{Working Group}

Working group was determined by convenience sampling method. The researcher worked with 15 geography students, and the researcher conducted in person their Cultural Geography course during 2016-2017 academic year spring semester. Except the three of the students, others come from out of the city. Students' academical success average is high. Due research ethics, participants' names were kept secret and participant students were named by codes of S1, S2... S15. The researcher made design for the implementation and prepared data collection tools. Later on, the researcher conducted the implementation, collected and analysed data and reported them. In the role of participant observer, the researcher was attentive to be objective during all process.

\subsection{Data Collection}

What is the impact of the FwDD-IGG model on problem-solving skills of prospective teachers? In order to answer the question, PSI-A was applied as the pre-test before application and as post-test after application. The inventory consists of 35 items describing how people are dealing with personal and daily life problems. This inventory developed as a Likert scale has a six replies option. The total score range from the inventory is 32-192. While a part of items of the scale which gathered under three sub-factors is expressed positive, the other part is expressed negatively. The high score on the scale indicates that the student perceives himself/herself as inadequate in problem-solving skills and the low score indicates that the problem-solving skill perception is high (Şahin, Şahin, \& Heppner, 1993).

Semi-structured interviews were used in the focus group interviews. The researcher, have the flexibility to ask additional questions to get more depth information if necessary besides his/her pre-prepared questions (Yıldırım \& 
Şimşek, 2011, p.122). In this study, the focus group interview was selected because the participants can hear each others' expressions and that might encourage them to make additional comments. Also, the subject discussed here is nor individual neither sensitive (Yıldırım \& Şimşek, 2011, p.151).

What are the opinions of prospective teachers regarding the FwDD-PBL learning process? In order to find answers to that question, students' opinions on PBL approach and producing their own digital documentaries via fieldwork were consulted. The questions' titles asked them are as fallows: Which skills did they earn from PBL? How did they work together? How did they research and learn? What are the disadvantages and advantages of PBL and FwDD? What did they think about on FwDD-PBL and the historical cultural places where they did the search? How was the teacher's performance? What did they learn in producing their own video? In which subjects had they lived problems and how did they solve them?

The study was conducted on the pilot study in 2014-2015 with another group of teacher candidates, consist of 48. And the semi-structured interview guide first applied to them, later on, before this implementation it was reviewed by 2 research assistants and one field specialist and rearranged in line with the feedback received. The focus group interview was conducted with all the goups members. During the research process, interviews were recorded.

\subsection{Analysis of Data}

PSI-A and focus group interview data collection techniques were used in combination to increase the validity of the measurements in the study. Transcripts of interview recordings with which were carried out the study grup were analyzed by content analysis method. To provide the validity of the study, tape recording was made, by receiving permission for focus group interviews; Data were tried to be collected with an objective approach. Data and results, obtained by the researcher, were compared with each other continuously, evaluated and were associated; to an expert opinion was consulted in preparation phase of data collection tools; by conducting open-ended questionnaire to students, their expressions in focus group interviews were tested and participant confirmation was provided. Since the working group consisted of 15 geography teacher candidates, generalizability of results to research population is limited; results can be only generalized for groups having similar characteristics. Direct quotations were included in findings to provide reliability. The researcher analyzed interview data 3 times two weeks apart through rest-retest method, tried to provide consistency of results and reflected the implementation process as it was.

\subsection{Implementation}

This study consists of two phases, including theoretical phase which the content of cultural geography course is given and project works. During the first two week of the implementation, the teacher introduced basic concepts of course to students and gave information on project-based teaching method. The teacher distributed course instruction to them. The content of course instruction as falows: Aims and outcomes of course, What is project-based learning approach? How is short movie made through Movie Maker program? Evaluation criterias for digital documentary, Rubric to evaluate presentations, Quizzes, Scoring criterias. The content of group portfolio as falows: Semi-structured group diary form, Criteria for project-research report of group, Self- and peer-assessment scale and other group materials. Later on, students being 15 in total formed their own groups. $1^{\text {st }}, 2^{\text {nd }}$ and $4^{\text {th }}$ groups consist of 4 students and $3^{\text {rd }}$ group of 3 students.

In the theoretical phase which was structured as student-based, students carried out group presentations within four weeks. After their presentations, groups were evaluated by the researcher and students. Immediately after this first stage, PSI-A was applied as pre-test to students. In the second phase of the implementation, it was passed into project phase of the lesson in order for students, who learned theory of the course, to put their knowledge into practice. The digital documentary that was the project product was developed through fieldwork. During the first week of this process, students made their intra-group discussions and made decision for their project subjects under the teacher's guidance. Throughout next two weeks, students carried out their group sessions in the lesson. During this process, the teacher examined studies performed by students every week, and however, the teacher was attentive to intervene in students' studies as little as possible. During last four weeks of the process, groups made digital documentary presentations and strengths-weaknesses of their works were discussed within the class after the presentation. Immediately after the final presentation of the project finished, PSI was applied to students as post-test. Project-based digital documentary production process lasted 28 hours and 14 weeks in total (Figure 1). When taking self- and peer-assessment scale, applied to students at the last week, into consideration, it was detected that there were a good work and learning environment, but that little intra-group disputes the extent to which will not hinder the process of the study happened in 1 st and 2nd groups. The teacher's observations were also same. The teacher visited each group in classroom group sessions and provided indirect guidances, by observing students' processes. However, students neither have experienced project-based learning method nor have carried out short film activitity systematically before. Students being familiar to traditional method could not duly utilize in-class sessions. Students reeled under heavy workload in a limited time, when they proceeded to documentary production process. 


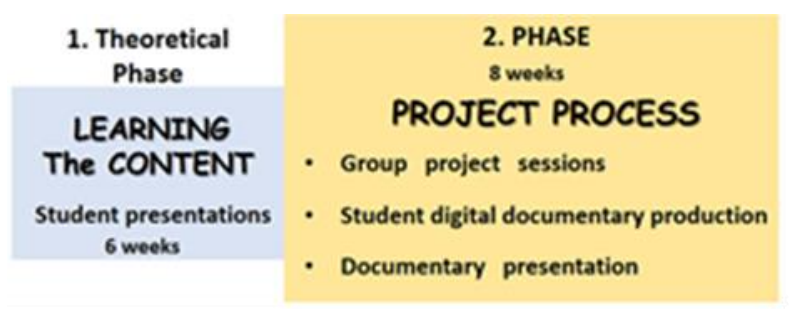

Figure1. FwDD-PBL process

Students were asked not to digress from project subjects in project preparation sessions and to give relevant outcomes of the course on their videos as simple and impressive as possible. During the period of digital documentary production in the field study, students performed the videos in the order specified by Akbaş (2011). Students studied the aims and outcomes of cultural geography course in theoretical phase. They then created the subject and scenario of their documentary according to their purpose and outcomes. They selected the subjects and the scripts as the target group of the high school students. In step 3, they decided to use their smartphones as a means of shooting. Only the 4th group, was able to supply a camera and tripod. At this stage, the effect of light, sound, indoor or outdoor places on the quality of the shooting. 4. In the process, the students made shootings and transferred them to their computers. They showed their videos in the classroom sessions, and asked the idea of teacher. The group members mostly did not like the first shot they made, they did video shooting and editting again for 4-5 times. In the final step, the documentary was presented to the class and evaluated by the students.

Project subjects are museums of Erzurum, religious and historical architecture buildings in Erzurum, Erzurum speech \& local food-clothing culture, urban renewal \& local architecture. After the implementation, the researcher conducted an open-ended questionnaire to students, for which they should evaluate their group videos and some materials of group portfolios. According to results of the questionnaire, the best academical research report and diary were prepared by $1^{\text {st }}$ group. The most-liked feature of $2^{\text {nd }}$ group study was the visualization of Twin Minarets Madrasa. It was stated that documentary of third group had the best image and sound quality although they shot by mobile phone. Also, the group's scenario and editing were chosen as the most original work among all works. $4^{\text {th }}$ group's work was the one where the course content convenient most with the video image and scenario.

\section{Results}

\subsection{What Are Teacher Candidates' Opinions on the Usability of FwDD-PBL Learning Model?}

Results of the content analysis were given in tabulars under four themes; (1) Applicability of digital documentary production project via fieldwork, (2) Disadvantages of the producing digital documentary via fieldwork, (3) The role and qualification of teacher in Fwdd-PBL, (4) Applicability of the Digital Documentary Project

Table 1. Student opinions on usability of FWDD-PBL

\begin{tabular}{|c|c|c|}
\hline Category & Code & $\mathrm{f}$ \\
\hline \multirow[b]{2}{*}{ FWDD-PBL Effect on Learning } & Learning through inquiry & 8 \\
\hline & Permanent Learning & 3 \\
\hline \multirow{7}{*}{$\begin{array}{l}\text { Social Skills Which Are Gained by } \\
\text { FWDD-PBL }\end{array}$} & Reporting skill & 3 \\
\hline & Communication skill & 5 \\
\hline & Presentation skill & 7 \\
\hline & Gaining self-confidence & 6 \\
\hline & Time management skill & 3 \\
\hline & Problem solving skill & 10 \\
\hline & Reflective thinking skill & 13 \\
\hline \multirow{4}{*}{ FWDD-PBL Effect on Cognitive Skills } & Positive attitude to the fieldworks. & 10 \\
\hline & Developing Positive Attitude to Historical, & 6 \\
\hline & Cultural and Geographical Elements & \\
\hline & Developing positive attitude towards PBL & 4 \\
\hline
\end{tabular}
FWDD-PBL

8 of 15 students stated that that they learned by researching during learning process of FwDD-PBL: S7: You encounter lots of data while researching on internet. We chose according to the interest to our subject and how we will establish its connection with cultural geography. A student's opinion that the process provided permanent learning is such: S3: Learning by doing and touring as such is a much more permanent learning. 3 students stated that they gained the reporting skill in the category of social skills which are gained by FWDD-PBL. A student's opinion on this code is like 
that: S2: First of all, project report of the group was not going to be a nonsense report... Ultimately, this video is an academical study. S7's opinion, who said that his communication skill increased, is like that: I was making it constantly on computer, I was bringing it by putting into mobile phone, we were watching it, and we were making joint decision which intro should be. 7 students laid emphasis on the fact that particularly their presentation skills increased. Among these: S10:' Diction... We improved our diction while I was getting ready for that presentation with S9. A student's opinion, who said that the process gained self-confidence, is like this: S15: But, I gained self confidence much, I couldn't go and speak to anyone previously, but now I speak very comfortably to even someone in the Street.S13, expressed the importance of time management skills: We have not been able to make good use of our time. Because we have never worked in such a long term, systematic way. Although we've deficiencies, we managed to finish the movie. A high number of students stated that they have gained problem solving skills: S6: And the wind, the screen was not constant and it was deforming the sound. First, we identified the problems. And we focused on them. S5: Our crisis management was good; we had to do some shots in one go and we made the right instant decisions at that time. Almost all of the students made reflections at their expressions: S10: I've begun to writing systematically my thoughts. I was thinking while I was writing in our group research journal, how I would make progress, how should I work, like a mathematical formula. In the category of FWDD-PBL's impact on cognitive skills, students stated that they developed a positive attitude towards fieldworks. A student's statement on this subject is: S4: We have seen that geography is not just a class lesson. We observed the environment, interviewed people, entered the human geography, completely independent of the class. Nearly half of the students stated that they've developed a positive attitude towards historical, cultural and geographical elements: S7: I was wondering, obviously... We went to see that places in ourselves because we want to see that venues...S8: We do not protect our cultural values or know them. 4 students said that they developed a positive attitude towards PBL. One of these: S7: We did our own documentary with the project based learning... I think that it is more effective than the exam. This method is very convenient to the course of cultural geography, because there are many cultural elements around. Also our self-confidence and entrepreneurship in society have increased by PBL. 3 students expressed their views on process and outcome-oriented evaluation. One of them: S2: But... when you look at the process in general, people able to see all the effort, the process of producing video, there. Otherwise, you can only see the result.

Table 2. Student opinions on disadvantages of FwDD-PBL

\begin{tabular}{lllc}
\hline Category & Code & $\mathrm{f}$ \\
\hline Inadequate Communication & $\begin{array}{l}\text { The Structure of Groups and Insufficient } \\
\text { Cooperation }\end{array}$ & 9 \\
\hline $\begin{array}{l}\text { Not Being Familiar with The PBL } \\
\text { Method }\end{array}$ & Lack of PBL experience & 4 \\
\hline
\end{tabular}

The opinion of some students regarding the structure of groups and insufficient cooperation in the inadequate communication category is as follows: S2: I think that it is better to be in a group formed by the teacher randomly, students can interact, know each other. A group formed by students themselves, close friends... They already know each other. It is not fair. The students' opinions on having a lack of PBL experience as fallows: S1: Taking points with a group study may seem strange to us. S11: Why hasn't the teacher taught the lesson as normal? Why did she want us to produce a digital documentary... I was so prejudiced.

Table 3. The role and qualification of teacher in FwDD-PBL

\begin{tabular}{lll}
\hline Category & Code & $\mathrm{f}$ \\
\hline $\begin{array}{l}\text { The Duties and Responsibilities of The } \\
\text { Teacher Are Sufficient in PBL }\end{array}$ & Student guidance level is sufficient & 6 \\
Submit a Recommendation & Motivate students & 2 \\
\hline & $\begin{array}{l}\text { Suggestions regarding the learning } \\
\text { process }\end{array}$ & 3 \\
\hline
\end{tabular}

A students' view on student guidance level is sufficient code in the category of the duties and responsibilities of the teacher are sufficient in FwDD-PBL learning strategy as fallows: S8: If you said to us what should we do definitely, than we couldn't produce a documentary like this. So I think it was better for us to search ourselves to decide what to do except the course criteria. One of the phrases of the students that they had motivated by the teacher as fallows: S14: The students did something normal but you did not just criticize but also you said good points; it motivated us. One of the recommendations for the learning process: S7: Even during the filming, more than one short video fragment appears. If you do not combine these pieces right away, then you have a heap in your hand, you can not organize them. Tell your students to do this in your next practice. 
Table 4. Student opinions on the applicability of the FwDD-PBL

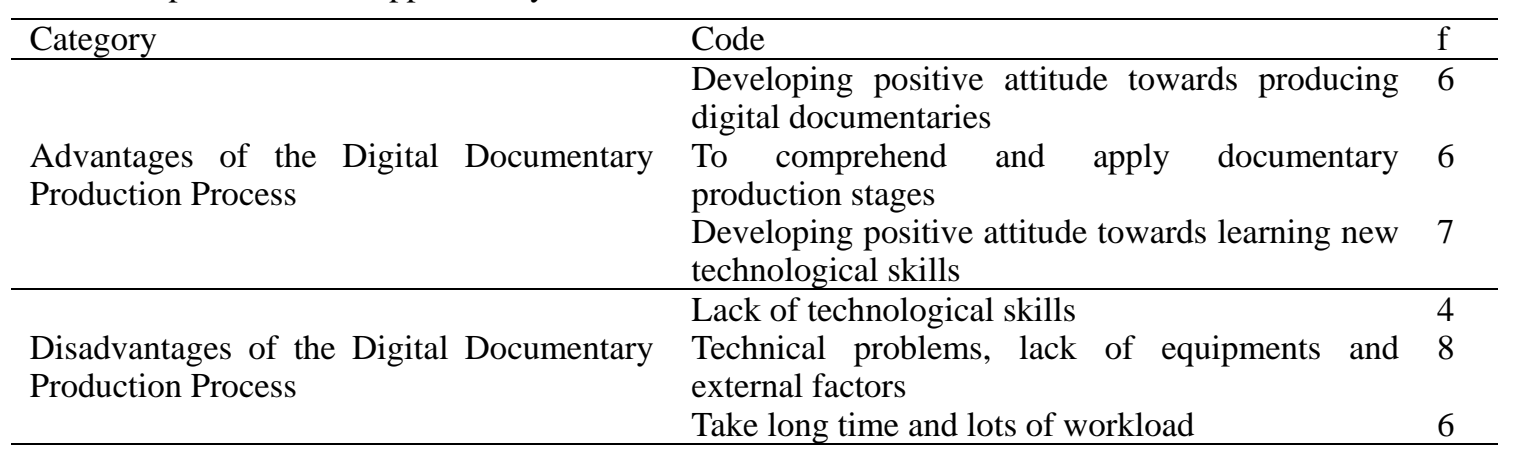

In the category of advantages of the digital documentary production process, students have developed a positive attitude towards producing digital documentaries. One of the views in this regard is: S9: As we were working in this short film project, the things we do are getting better and better, so we've gotten ourselves into more project. It's very motivating. In the process, it was seen that students could understand and apply the stages of documentary production. One of the student opinions on this subject is as follows: S6: For example, you are in the class and filming the video; you see that the light shines in the place too much so we close the curtains, turn on the light, turn the smartboard image at the background to black. For example, some of the local foods of Erzurum are also famous in the cities like Bayburt, it is in the neighbourhood. That means there is a cultural expansion here because we also see Erzurum's local food in Bayburt. This shows that the domain of Erzurum is wide; we connected them in this way. We didn't live much diffuculties at connecting the content of the course and the documentary... Cause we already had learned them at theoretical stage. It has been seen that students acquire positive attitudes towards learning new technological skills. One of the student opinions in this regard is: S7: Now, after this project, I am more curious about technology. I am looking at new programs, trying to learn.

In the category of disadvantages of the digital documentary production process, students have had some problems like mounting, shooting techniques, learning and application of new softwares because of their lack of technological skills. One of the student opinions on this topic is: S11: We did not find the use of a tripod at U TUBE. Finally, we maneged to use it by learning trial and error. Students have experienced technical problems such as poor performance of computers, lack of cameras, lack of permission shooting in some places where they were doing research, lack of light and sound equipments in their hands, cloudy wheather and external factors. Some student expressions on this subject are as fallows: S10: Because we are filming at outdoors... The indoor area has a quietness of its own accord. If you have noticed, the wind and the external sounds in the video. So we would shoot the best video if we were at indoors. Students stated that digital documentary production takes a long time and there is a lot of workload. Some student expressions on this subject are as falows: S3: You only need two days for a written examination. But such a video-presentation requires two to three weeks. S5: The production of the project is a little tiredness and insomnia. Unexpected problems, extra work... And all these takes a long time.

3.2 What Is the Effect of the FwDD-PBL Model on the Problem-Solving Skills of Prospective Teachers?

Statistical data on the Problem Solving Inventory are given in Table 5 and Table 6.

Table 5. Descriptive Statistics for Problem Solving Inventory

\begin{tabular}{llllll}
\hline Test Type & & $\mathrm{N}$ & $\mathbf{X}$ & SD & SE \\
\hline & Pre-test & 15 & 91.80 & 15.58 & 4.02 \\
$\begin{array}{l}\text { Problem } \\
\text { Solving }\end{array}$ & Post-test & 15 & 75.20 & 16.75 & 4.32 \\
\hline
\end{tabular}

Results of the Problem Solving Inventory (PSI-A) which were carried out to measure students' problem solving skills were given in Table 5. When results of Table 5 were examined, it was seen that there was a difference of 16.6 scores between averages of implementations of the pre-test and post-test and this was in favor of pre-test. Being high of total scores which were taken from PSI-A shows that individual has perceived oneself inadequate in problem solving. Since total score taken from post-test of PSI-A, was less in comparison with pre-test, there has been an increase positively in students' problem solving skills. But, Paired Samples Test was performed to determine whether this inventory made a meaningful difference in students' problem solving skills or not, and whether the effect of FwDD-PBL on problem solving skills was low, middle and high or not. Results belonging to this inventory were given in Table 6 . 
Table 6. Results of Paired samples T - Test for Problem Solving Inventory

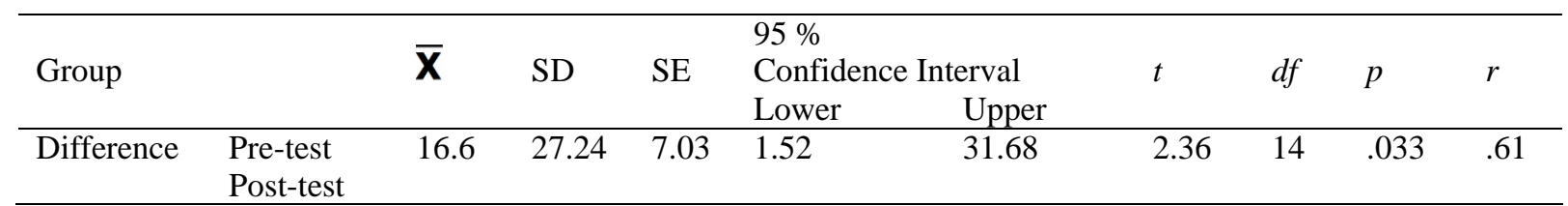

Paired Samples t-test was conducted to evaluate the effect of FwDD-PBL model, on values which were taken by students from problem solving inventory test. A statistically meaningful decrease in students' scores occured, from pre-test $(M=91,80, S D=15,58)$ to post-test $(M=75,20, S D=16,75) ; \mathrm{t}{ }_{(14)}=2,36, \mathrm{p}<.05$ (two-tailed). Average decrease in PSI-A values was found as 16.6 and values has the $95 \%$ confidience interval ranging between 1,52 and 31,68. Effect size $d$ statistics obtained (. 61) shows that a medium effect size. According to Green \& Salkind (2005, p. 157) and Morgan, et al. (2004, p. 91), $d$ value interpreted as the large effect when it is $0.8 ; 0.5 d$ value accepted as the middle; $0.2 d$ value means small effect (Can, 2014).

\section{Discussion and Conclusions}

When the study findings are examined, producing digital instructional videos by students as a learning strategy is an outcome of the project-based learning approach, as it is mentioned in the literature. Therefore, the findings of these two learning processes support each other. Fieldwork, like these two other approaches, provides out-of-class educational opportunities and is one of the basic teaching methods of geography. Therefore, the fieldwork method, the project-based learning approach and the findings of the student -video learning strategy were directly interpreted as common findings. Some of the highlights are also stated.

The findings obtained in the study revealed that FwDD-PBL increased the students' problem solving skills as well as their motivation, spirit of entrepreneurship and their self-confidence. In the light of the observations and the interviews held with the students, it was revealed that FwDD-PBL increased their communication skills, technological pedagogical content knowledge (TPACK), metacognitive skills and developed their skills in time management, presentation, reporting and technology use; that the students had positive attitudes towards FwDD-PBL; and that they were able to relate geography to daily life. Apart from this, students took their own learning responsibilities, learned by searching and had permanent information in a constructive learning environment. Study results show similarity with other studies dealing with project-based learning model and/or educational short film projects (Dede \& Yaman, 2003; Coşkun, 2004; Kajder, 2004; Ferster et al., 2006; Ranker, 2007; Kalaycı, 2008; Urbano \& Urbano, 2008; Siegle, 2009; Di Palma, 2009; Bıyıklı et al., 2008; Alper, 2011; Akbaş, 2011; Swan et al., 2011; Ay, 2013; Bene, 2013; Morgan, 2013; Demiray, 2013; Çrral1, 2014; Göçen, 2014; Kotluk \& Kocakaya, 2015; Akbaş et al., 2015; Urhan, 2016; Kızıltaş, 2017; Yiğit et al., 2017).

However, integration of digital technologies into the class may not always give the results that the trainers expected. For example, when using digital technology and the internet in the classroom, students organize their own learning and develop creative thinking skills but they have observed that these outcomes do not always contribute to students' academic achievement (Bene, 2013). On the other hand, in the FwDD-PBL learning process, it is understood that the students had difficulties at the first stage in this constructive approach model since they are used to traditional learning approach.

At the beginning of the treatment, students were unable to link producing their digital documentary to fieldwork, geography, or teaching. They have been prejudiced to the process because they have not done such practical work before. However, when they landed for the film, they have realized that they were doing a fieldwork, one of the basic research principles of geography. In addition to being a great motivation for all students, Siegle (2009) also point out that some students learn a concept more clearly with video. Students who perceived geography as a class lesson, had the opportunity so that they can practice their knowledge at the field, remember previous geography knowledge and relating them to the scenes in the field, and establish relations of geography with other areas. These findings are paralel to the research of Garipağaoğlu (2001), Gök \& Girgin (2001), Doğanay (2002), Demiralp (2007), Di Palma (2009), Balc1 (2010), Tuna (2012) and Şahin \& Özey (2013). The video creation process has the potential to provide much more academic benefits. Students often learn a topic when they create their own video and use it to show what they are learning (Siegle, 2009; Morgan 2013). Artvinli et al. (2003), Köşker (2012) and Yıldız (2015) stated that teachers do not have sufficient effective instruction and teaching skills. Doğru (2016), said that geography teachers' technology knowledge in TPACK is not enough. In the process of FwDD-PBL, effective instruction and teaching skills of teacher candidates also developed.

In addition, the efforts of the students to advertise the cultural venues on their field trips, in their documentaries and to transmit their messages in the most effective manner have led them to develop positive attitudes towards historical, cultural and geographical elements. Participants investigated these places in their video in detail. Gümüş \& Adanalı 
(2011), stated that secondary school students did not have enough knowledge and positive attitude towards the historical and cultural features of the place they lived in.

Depending on these findings, the researcher's suggestions:

- In the field of geography education literature, project-based learning, problem-solving skills, and digital documentary /short Film, digital storytelling studies, are not rich enough. New researchs on these subjects should be occurred especially focusing on the experiences of the students in the process, and the findings should be supported by quantitative data.

- The education technologies and material development course is a project-based learning course and within this course, students might be asked to prepare instructional digital short videos taking into account the technological-pedagogic-content knowledge.

- Teachers should be trained and certified for digital documentary /film applications.

- Short film competitions can be organized not only within certain institutions but even in the school or even in the classroom, encouraging the students. As a matter of fact, when the produced films are shared on the internet, everyone has the chance to reach, comment, criticize and develop this database.

- To increase the motivation and the academic skills of fieldworks students might be asked to produce a digital documentary or write an academic report, or both.

\section{References}

Akbaş, O. (2011). Bir öğrenme nesnesi olarak eğitsel kısa filmler: Öğretmen adaylarının çektikleri eğitsel kısa filmler üzerine bir değerlendirme. Gazi Üniversitesi Endüstriyel Sanatlar Eğitim Fakültesi Dergisi, 27, 15-27. Retrieved from http://dergipark.gov.tr/esef/issue/28793/308106

Akbaş, O., Canoğlu, S. N., \& Ceylan, M. (2015). Eğitsel kısa film ve videoları yeniden düşünmek: Eğitsel kısa film ve video yarışmasına ilişsin bir değerlendirme. Journal of Theoretical Educational Science/Kuramsal Eğitimbilim Dergisi, 8(2). Retrieved fromhttp://dergipark.gov.tr/akukeg/issue/29357/314133

Alım, M., \& Siyamoğlu, S. (2017). Coğrafya öğretmeni adaylarının akıllı cihazlarda coğrafi bilgi ve beceri kazandırabilecek uygulamaları kullanmalarına yönelik görüşleri. Doğu Coğrafya Dergisi, 22(38), 251-274. https://doi.org/10.17295/ataunidcd.298825

Alper, A. (2011). Probleme dayalı öğrenme. Ankara: Pelikan Tip ve Teknik Yayıncılık.

Artvinli, E., Kılıçarslan, A., \& Bulut, İ. (2003). Trabzon'daki liselerde coğrafya öğretmenlerinin etkili öğretme ve ders işleme becerilerinin öğrenci görüşlerine göre değerlendirilmesi. Doğu Coğrafya Dergisi, 8(10). Retrieved from http://e-dergi.atauni.edu.tr/ataunided/article/view/1021006277

Ay, Ş. (2013). Öğretmen adaylarının proje tabanlı öğrenme ve geleneksel öğretime ilişkin görüşleri. Hacettepe Üniversitesi Ĕ̆itim Fakültesi Dergisi, 28(1), 53-67. Retrieved from http://dergipark.ulakbim.gov.tr/hunefd/article/view/5000048042

Balc1, A. (2010). The opinions of the geography teacher candidates about the place of field trips in geography teaching. Education, 130(4), 561-573. (accessed 13 September, 2016)

Bene, R. E. (2013). Exploring metacognition and higher order thinking through digital video creation: A multiple case study (Order No. NS23810). Available from ProQuest Dissertations \& Theses Global. (1519315731). Retrieved from https://search.proquest.com/docview/1519315731?accountid=8403

Bıyıklı, C., Veznedaroğlu, R. L., Öztepe, B., \& Onur, A. (2008). Yapılandırmacılı̆̆ı nasıl uygulamalıyız? Ankara: Odtü Yayıncilik.

Birkök, M. C. (2008). Bir toplumsallaştırma aracı olarak eğitimde alternatif medya kullanımı: Sinema filmleri. Uluslararası Insan Bilimleri Dergisi. 5(2). https://doi.org/10.14687/ijhs.v5i2.574

Can, A. (2014). SPSS ile bilimsel araştırma sürecinde nicel veri analizi (3rd ed). Ankara: Pegem Akademi

Coşkun, M. (2004). Coğrafya öğretiminde proje yaklaşımı. Ahi Evran Üniversitesi Kırşehir Eğitim Fakültesi Dergisi. 5 (2). 99-107 (accessed 13 September, 2016)

Coşkun, M. (2010). Proje tabanlı öğretim sürecinin öğrencilerin coğrafya dersindeki yansıtıcı düşünme yeteneklerine göre değerlendirilmesi. Turk. Stud. J., 5(2), 897-911. (accessed 13 September, 2016)

Creswell, J. W. (2007). Qualitative inquiry and research design: Choosing among five traditions (2nd ed). London: Sage. 
Çıralı, G. (2014). Dijital hikâye anlatımının görsel bellek ve yazma becerisi üzerine etkisi (Unpublished master’s thesis). University of Hacettepe, Ankara, Turkey.

Dede, Y., \& Yaman, S. (2003). Fen ve matematik eğitiminde proje çalışmalarının yeri, önemi ve değerlendirilmesi. Gazi Üniversitesi Gazi Eğitim Fakültesi Dergisi, 23(1), 117-132. Retrieved from http://dergipark.ulakbim.gov.tr/gefad/article/view/5000078861

Demiralp, N. (2007). Coğrafya eğitiminde öğretim materyalleri. In S.Karabağ \& S.Şahin (Ed). Kuram ve Uygulamada Coğrafya Ĕ̈itimi (pp. 139-173) Ankara: Gazi Kitabevi.

Demiray, P. (2013). Proje tabanlı öğrenme modelinin etkililiği: Bir meta analiz çalı̧̧ması (Unpublished master’s thesis). University of Ankara, Ankara, Turkey.

Di Palma, M. T. (2009). Teaching geography using films: A proposal. Journal of Geography, 108(2). 47-56. https://doi.org/10.1080/00221340902967325

Doğan, A. (2016). Adlyaman Kentinde Coğrafya öğretim yöntem ve tekniklerinin coğrafya öğretimine etkisi. (Unpublished master's thesis). University of Harran, Şanlıurfa, Turkey.

Doğanay, H. (2002). Coğrafya Öğretim Yöntemleri. İstanbul. Aktif yayınevi.

Doğru, E. (2016). Coğrafya ögretmenlerinin Teknolojik Pedagojik Alan Bilgisi ile ilgili yeterliliklerinin incelenmesi (Unpublished master's thesis). University of Karabük, Karabük, Turkey.

Ferster, B., Hammond, T., \& Bull, G. (2006). Primary access: Creating digital documentaries in the social studies classroom. Social Education, 70(3), 147. (accessed 23 September, 2016)

Garipağaoğlu, N. (2001). Gezi-gözlem metodunun coğrafya eğitimi ve öğretimindeki yeri. Marmara Coğrafya Dergisi, 2(3), 13-30.

Girgin, M. (2012). Eğitim Filmleri-Başlar Yukarı! Vize yayınevi, Ankara

Göçen, G. (2014). Dijital öyküleme yönteminin öğrencilerin akademik başart ile öğrenme ve ders çalışma stratejilerine etkisi (Unpublished master's thesis). University of Muğla Sttkı Koçman, Muğla, Turkey.

Gök, Y., \& Girgin, M. (2001). Ortaöğretim Coğrafya Programında Deney ve Gezi- Gözlemin Önemi, Doğu Coğrafya Dergisi, 7 (6), 61-73 (accessed 15 September, 2016)

Gümüş, N., \& Adanall, R. (2011). The attitude and behavior of students in high school towards historical and cultural heritage in Buca (İzmir). Buca Faculty of Education Journal, (30), 87-102. Retrieved from http://dergipark.gov.tr/deubefd/issue/25121/265268

Kajder, S. B. (2004). Enter here: Personal narrative and digital storytelling. English Journal, 64-68. https://doi.org/10.2307/4128811

Kalayc1, N. (2008). Yükseköğretimde proje tabanlı öğrenmeye ilişkin bir uygulama. Eğitim ve Bilim. 33(147). Retrieved from http://eb.ted.org.tr/index.php/EB/article/view/691

Kaplan, A. Ö., \& Coşkun, Y. D. (2012). Proje tabanlı öğretim uygulamalarında karşılaşılan güçlükler ve çözüm önerilerine yönelik bir eylem araştırması. Mersin Üniversitesi Eğitim Fakültesi Dergisi, 8(1).137-159. Retrieved from http://dergipark.ulakbim.gov.tr/mersinefd/article/view/1002000168

Kızıltaş, T. N. (2017). Fen bilimleri dersi öğretiminde proje tabanlı öğrenme yönteminin uygulanmasina yönelik ögretmen ve ögrrenci görüşleri: Muş örneği (Unpublished master's thesis). University of Muş Alparslan, Muş, Turkey.

Korkmaz, H., \& Kaptan, F. (2001). Fen eğitiminde proje tabanlı öğrenme yaklaşımı. Hacettepe Üniversitesi Eğitim Fakültesi Dergisi, 20(20). Retrieved from http://dergipark.ulakbim.gov.tr/hunefd/article/viewFile/5000048898/5000046218

Kotluk, N., \& Kocakaya, S. (2015). 21.yüzyıl becerilerinin gelişiminde dijital öykülemeler: Ortaöğretim öğrencilerinin görüşlerinin incelenmesi. Eğitim ve Ögrretim Araştırmaları Dergisi. 4(2). Retrieved from http://www.jret.org/FileUpload/ks281142/File/36.nihat_kotluk..pdf

Köşker, N. (2012). Coğrafya eğitiminde yer temelli öğretim yaklaşımına ilişskin öğretmen görüşleri (Unpublished doctoral dissertation). University of Gazi, Ankara, Turkey.

Metzger, S. (2010). Maximizing the Educational Power of History Movies in the Classroom. Social Studies, 101(3), 127-136. https://doi.org/10.1080/00377990903284047

Morgan, H. (2013). Creating videos can lead students to many academic benefits. Childhood Education, 89(1), 51-53. 
https://doi.org/10.1080/00094056.2013.757534

Ranker, J. (2007). A New Perspective on Inquiry: A Case Study of Digital Video Production.The English Journal 97(1), 77-82. https://doi.org/10.2307/30047212

Russel, W. (2006). Secondary social studies teachers use of film: A comparison study (Doctoral dissertation, University of Florida, Florida, USA). Retrieved from https://www.learntechlib.org/p/116369/.(accessed 04 September, 2016)

Siegle, D. (2009). Literacy in the 21st century: The fourth R-video recording. Gifted Child Today, 32(2), 14-19. Retrieved from https://search.proquest.com/docview/203261382?accountid=8403 (accessed 13 March, 2016)

Social Business TR (7 June 2017). 2017 Sosyal Medya İstatistikleri. Retrieved from http://www.socialbusinesstr.com/2017/06/07/2017-sosyal-medya-istatistikleri/ (accessed 03 October, 2017)

Swan, K., Hofer, M., \& Swan, G. (2011). Examining authentic intellectual work with a historical digital documentary inquiry project in a mandated state testing environment, Journal of Digital Learning in Teacher Education, 27(3), 113-122 (accessed 11 September, 2016)

Swimelar, S. (2012). Visualizing international relations: Assessing student learning through film, International Studies Perspectives, 14(1), 14-38. (accessed 13 September, 2016)

Şahin, N., Şahin, N. H., \& Heppner P. P. (1993). Psychometric properties of the Problem Solving Inventory in a group of Turkish University Students. Cognitive Therapy and Research, 17(4), 379-397.

Şahin, V., \& Özey, R. (2013). İngiltere'de lisans düzeyinde coğrafi arazi çalışmaları. Marmara Coğrafya Dergisi, 0(25), 1-17. Retrieved from http://dergipark.gov.tr/marucog/issue/472/3851

Tuna, F. (2012). Current situation and analysis of geography teachers' active learning knowledge and usage in Turkey. Educational Research and Reviews, 7(18), 393.

Tüzel, S. (2013). Çok katmanlı okuryazarlık öğretimine ilişkin Türkçe öğretmen adaylarının görüşlerinin incelenmesi. Eğitimde Kuram ve Uygulama, 9(2), 133-151. Retrieved from http://eku.comu.edu.tr/article/view/1044000172

Urbano, L. D., \& Urbano, L. C. (2008). Learning through movie production with the MovieClassroom. Journal of Geoscience Education, 56(4), 334-341. Retrieved from https://search.proquest.com/docview/202780406?accountid=8403

Urhan, N. (2016). İşbirlikli proje tabanlı öğrenme sürecinde dijital belgesel üretiminin yansitıcı düşünmeye katklsı(Unpublished master's thesis). University of Hacettepe, Ankara, Turkey.

Yıldırım, A., \& Şimşek, H. (2011). Sosyal bilimlerde Nitel Araştırma Yöntemleri. Ankara: Seçkin Yayınevi

Yıldız, A. (2015). Lüleburgaz lise coğrafya öğretmenlerinin coğrafya öğretim yaklaşımları (Unpublished master's thesis). University of Süleyman Demirel, Isparta, Turkey.

Yiğit, N., Alev, N., Yurt, Ö., \& Mazlum, E. (2017). Kısa film tasarımlarında teknolojik ve pedagojik özelliklerin incelenmesi, Turkish Online Journal of Qualitative Inquiry (TOJQI) 8(1), 122-140. Retrieved from http://dergipark.gov.tr/download/article-file/272066

Yin, R. K. (2003). Case Study Research: Design and Methods (third edition). Beverly Hills, CA: Sage.

\section{Copyrights}

Copyright for this article is retained by the author(s), with first publication rights granted to the journal.

This is an open-access article distributed under the terms and conditions of the Creative Commons Attribution license which permits unrestricted use, distribution, and reproduction in any medium, provided the original work is properly cited. 